\title{
Hidden Casualties: The Links between Armed Conflictand Intimate Partner Violence in Colombia
}

\author{
Signe Svallfors
}

\section{Stockholm University}

The Colombian peace process was internationally celebrated for its unprecedented focus on women's experiences of war, but the everyday violence women that may face in their homes was not acknowledged. This article explores the links between exposure to local armed conflict violence and individual women's experiences of intimate partner violence. I combine pooled nationally representative data on individual women's experiences of intimate partner violence with information about the intensity of conflict during 200416. Results of fixed-effects linear probability models show that conflict was generally linked to a slightly elevated risk of women experiencing emotional, physical, and sexual violence perpetrated by their partner. Among women who had experienced intimate partner violence, conflict was related to an increased probability of being partnered at interview, which could reflect women staying in abusive relationships because conflict normalizes violence or increases women's reluctance to leave those relationships.

Keywords: Intimate partner violence, armed conflict, gender, women's health, Colombia

7 he Colombian peace process between the government and the left-wing 1 guerrilla FARC (Revolutionary Armed Forces of Colombia) has been internationally celebrated for its unprecedented focus on women's experiences of armed conflict. After substantial efforts by Colombian civil society led to an exceptional inclusion of women in all aspects of the negotiations, the Havana Peace Accords, ratified in 2017, recognized the particular effects of war on women, most notably in terms of sexual violence (Gindele et al. 2018; Salvesen and Nylander 2017). But the everyday

(C) The Author(s), 2021. Published by Cambridge University Press on behalf of the Women, Gender, and Politics Research Section of the American Political Science Association. This is an Open Access article, distributed under the terms of the Creative Commons Attribution licence (http://creativecommons.org/licenses/by/4.0/), which permits unrestricted re-use, distribution, and reproduction in any medium, provided the original work is properly cited. doi:10.1017/S1743923X2100043X 
violence that women may face in their homes was not acknowledged in the otherwise gender-comprehensive accords.

Conflict-related sexual violence (CRSV) is a known feature of many conflicts worldwide. It does not occur in a vacuum, but it may reflect the overall status of women in a society and a larger culture of gender-based violence (GBV) in both peace and war. An exclusive focus on CRSV overlooks violence against women in the private sphere (Gray 2019; Kirby 2015; McWilliams and Ni Aolain 2014). This article explores the link between local conflict violence and individual women's experiences of intimate partner violence. Building on the feminist notion that "the personal is political," I problematize how violence committed in the "public sphere" is more readily acknowledged, while the connections between women's experiences of violence in "private" and larger sociopolitical structures are made invisible.

GBV is a global problem of pandemic proportions (Devries et al. 2013). It is a severe violation of women's integrity and rights, with great population health costs (Heise 1994). GBV is associated with unintended pregnancy and abortion (Gomez 2011; Pallitto et al. 2013), contraceptive nonuse (Svallfors and Billingsley 2019), self-reported ill health (Ellsberg et al. 2008), suicidal thoughts and attempts (Devries et al. 2011; Ellsberg et al. 2008), and societal gender equality (Heise and Kotsadam 2015; Yodanis 2004). Hence, understanding GBV during war is a matter of recognizing human security beyond armed groups and how different forms of violence are interlinked. It also adds to our comprehension of how contextual factors such as exposure to violent conflict shape lives, social relations, and the risk of gendered violence at the micro level.

The term "gender-based violence" illustrates violence related to hierarchies between sociobiologically ascribed categories such as gender. It is manifested in many forms, such as rape, sexual assault and exploitation, child and forced marriage, and forced contraception, abortion, and adoption. I use the term "intimate partner violence" and its abbreviation IPV here since the analyses are restricted to this form because of the lack of information on men's and gender minorities' victimization and violence against women by other perpetrators.

This study builds on a small body of quantitative research in which women's exposure to local conflict has been linked to a higher risk of experiencing IPV at the population level (La Mattina 2017; Østby 2016; Østby, Leiby, and Nordås 2019; Rieckmann 2014). ${ }^{1}$ Compared with

1. For a systematic review of non-randomized service-based and refugee camp studies, see Stark and Ager (2011). 
previous studies on Colombia (Rieckmann 2014), I use monthly instead of yearly conflict data and disentangle different forms of IPV. This enables more precision in the analysis of the timing of violence and facilitates a better understanding of the complexities of violence that women may face. I propose a systematic framework of multiple micro- and macrolevel mechanisms by which conflict could be associated with a higher risk of IPV. The article also contributes with novel analyses of how conflict exacerbates women's victimization by reducing their likelihood of leaving violent relationships.

Colombia is a particularly interesting case for studying the relationship between conflict and IPV. First, the peace process, with its unique gender focus, provides a moment of opportunity for research and policy efforts targeting GBV in all its diversities. Insights from this study can inform prevention programs and transitional justice interventions in Colombia and beyond. Second, Colombia has had a uniquely long-term conflict with large variation across space and time in violence intensity (Bergquist, Peñaranda, and Sánchez 2001). Third, unlike most humanitarian settings, long-term, high-quality, nationally representative data are available on the prevalence of IPV (DHS 2005, 2011, 2017).

\section{MECHANISMS AND PROXIMATE DETERMINANTS OF INTIMATE PARTNER VIOLENCE IN ARMED CONFLICT}

I propose a systematic framework that operates on the macro and micro levels to explain how conflict may spill over into relationships in a way that could affect women's risk of experiencing violence, as illustrated in Figure 1. On the macro level, conflict may shape the dynamics of a society or a community in a way that undermines women's safety. On the micro level, conflict may have effects on relationships and individuals that enable violence against women. These mechanisms are not mutually exclusive and are perhaps mutually enforcing (Müller and Tranchant 2019). The hypothesis is that exposure to conflict is associated with a higher probability of being exposed to IPV.

\section{Normative Shift of Power Dynamics}

In societies and communities plagued by violent conflict, a normative shift of power dynamics that condones IPV in general may occur if gender norms are militarized or patriarchal attitudes are amplified. This may be particularly relevant in protracted conflicts such as that in Colombia. 


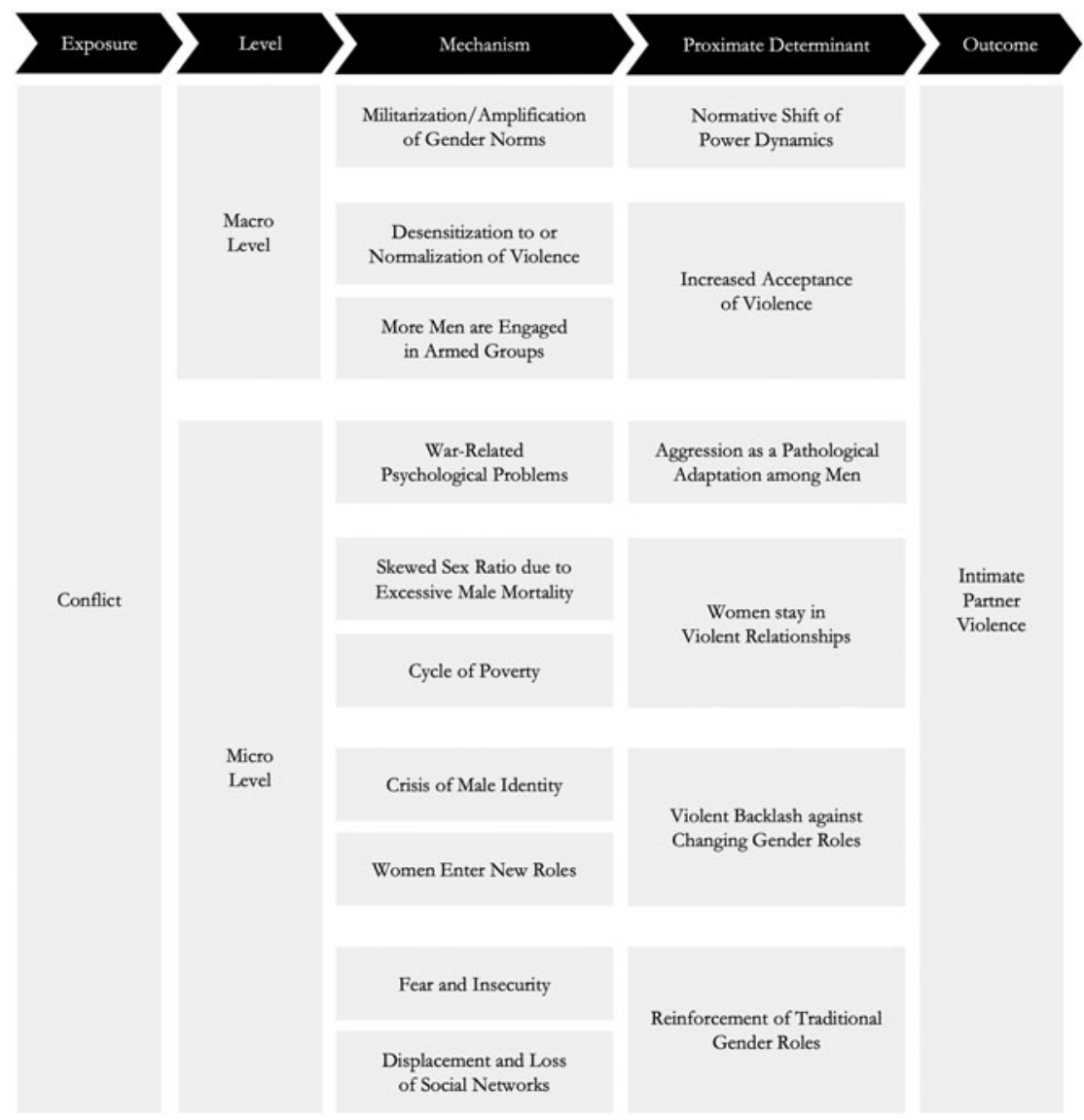

FIgURE 1. Mechanisms between armed conflict and intimate partner violence.

Community-level gender unequal attitudes are known to drive the risk of IPV for individual women (Ackerson and Subramanian 2008; Cools and Kotsadam 2017; Koenig, Ahmed et al. 2003; Koenig et al. 2006; Vyas and Heise 2016). Scholars have argued that gender relations in war are based on preexisting gender norms, calling to attention how IPV may occur as an amplification of patriarchal attitudes and practices (Alsaba and Kapilashrami 2016; Brownmiller 1976; Henry 2016; Milillo 2006; Sengupta and Calo 2016).

Building on Connell's (2002a, 2002b; Connell and Messerschmidt 2005) concept of hegemonic masculinity, "militarized masculinity" is a useful term to explain changes in gender norms during conflict. It 
identifies the soldier as hegemonic within armed groups, where militarized masculinity is socialized in profoundly male-dominated organizations. It is not a cultural constant but pervades societies and time with few exceptions because even though most men are not soldiers, most soldiers are men (Connell 2000; Goldstein 2001; Parpart and Partridge 2014; Rones and Fasting 2017; Wadham 2017).

Conflict may amplify patriarchal gender norms in the process of militarization, which has the capability to transform the meanings of people, things, and ideas far beyond the battlefield. The basic assumptions of militarism are that armed struggle is the best solution to conflict, human nature is prone to conflict, and men who do not participate in fighting (such as conscientious objectors) are unpatriotic and feminized (Bibbings 2012; Clark 1946; Enloe 2002; Jones 2006). Militarism and patriarchy are not inseparable, but the first tends to privilege the other by constructing both masculinity and femininity in parallel (Enloe 2000, 288-300) through designating the role of arms and politics to men and the role of caregiving to women (Cockburn and Zarkov 2002). Sexual violence can be a strategy for armed groups to create social ties and socialize norms about masculinity (Cohen 2017). Large-scale, masculinity-affirming CRSV could increase in tandem with other forms of GBV, including IPV.

\section{Increased Acceptance of Violence}

Also at the macro level, acceptance of IPV may increase within a society or community if violence overall becomes normalized in the context of conflict and if more men engaging in armed activities creates a compositional change. This pathway, too, may be more salient in longterm conflicts.

War tends to have a desensitizing effect on the perception of violence and create a dehumanized view on victims (Annan and Brier 2010; Wood 2014). Increased acceptance of violence can also occur in tandem with an amplification of patriarchal norms. When men are thought of as inclined to force by nature or nurture, men's violence may be normalized and condoned regardless of whether it is committed by soldiers or civilians. Violence against women, then, may not be considered a "real" crime, as the behavior is regarded "part and parcel of being male" (Bibbings 2012, 51). Community-level IPV and homicide rates have been connected to individual risk of IPV (Koenig et al. 2006; 
McQuestion 2003; Pallitto and O'Campo 2005), perhaps reflecting a macro-level normalization.

\section{Aggression as a Pathological Adaptation among Men}

At the individual level, war trauma may cause psychosocial problems, which, in turn, may cause more IPV if men develop aggression as a pathological adaptation to a violent environment.

We can expect changes in norms and behavior among witnesses of violence in families (Pollak 2004) and communities. Responses to trauma tend to vary across gender, as men are more prone to develop aggression, while women are more likely to show signs of depression (Mead, Beauchaine, and Shannon 2010; Ng-Mak et al. 2004; SchwabStone et al. 1995). Young boys and girls express emotions similarly, but they are typically socialized later to do so differently. Boys and men are often taught to suppress emotion even when faced with war atrocities, or risk shame and death. GBV may be enabled by constructing masculinity through emotional suppression to enhance men's war capabilities (Goldstein 2001; Montes 2013).

IPV is sometimes condoned as an inevitable by-product of conflict through the medicalization of war traumas that naturalize everyday militarized gender roles by portraying violent behavior as a mental illness (Gray 2016b). Mental health disorders have been linked to both conflict (Tamayo-Agudelo and Bell 2019) and IPV perpetration (Yu et al. 2019). Violent behavior may be reinforced if men turn to alcohol and drugs to deal with trauma, poverty, and loss of identity; substance abuse has been consistently linked to violent abuse (Hindin, Kishor, and Ansara 2008; Kishor and Johnson 2004; Koenig, Ahmed, et al. 2003; Koenig, Lutalo, et al. 2003; Mootz et al. 2018; Sengupta and Calo 2016; Yu et al. 2019).

\section{Women Stay in Violent Relationships}

At the micro level, women's trauma and changes to relationship dynamics and socioeconomic conditions may lead to victims' acceptance of violence and increased propensity of staying in abusive relationships (Friedemann-Sánchez and Lovaton 2012). Since breaking up a violent relationship may be the time when women are most at risk of vengeful acts of violence, women could be reluctant to leave (Stanko 1997). Additionally, areas with high levels of conflict may have less institutional 
support for victimized women (Svallfors 2021). Potentially, a higher frequency of IPV related to conflict could result from relationships that would otherwise have dissolved but did not, and not necessarily only from new violence in relationships that were previously free from abuse.

IPV is often theorized as a result of power dynamics (Goode 1971; Heise 1998) based on material, economic, and social resources in a relationship (Miedema, Shwe, and Kyaw 2016). The relative and absolute socioeconomic status of the victim, partner, and community are often discussed as central proximate determinants of IPV (Cools and Kotsadam 2017; Friedemann-Sánchez and Lovaton 2012; Svec and Andic 2018; Vyas and Heise 2016; Yount 2005). Women with better resources may be more able to leave an abusive relationship as well as conflict areas, and conflict-induced poverty could hinder women from staying safe.

In war contexts, being "a good man" often means taking up arms to protect the family. Choosing a partner who is engaged in an armed group can be a protection measure, putting women at risk of "domestication" of violence (Theidon 2009). Women may stay in an abusive relationship if excessive male mortality in conflict creates a skewed sex ratio, with fewer prospects of forming a new relationship (Jones and Ferguson 2006; La Mattina 2017). La Mattina (2017) found that women were no more accepting of IPV to explain their increased victimization, but trauma may lower their self-esteem (Carlton-Ford, Ender, and Tabatabai 2008) and make them less avoidant of harm (Mead, Beauchaine, and Shannon 2010) without changing normative beliefs.

\section{Violent Backlash against Changing Gender Roles}

Given how conflict disrupts the social fabric and reorganizes resources, gender dynamics are likely to shift at multiple levels. Men may exercise IPV as a control instrument if conflict changes gender roles within couples - for example, if men lose labor market opportunities or if women enter new economic and political roles.

IPV has been discussed as a violent backlash against women's decisionmaking or resource attainment challenging hegemonic male breadwinner norms (Burazeri et al. 2005; Cools and Kotsadam 2017; Gupta et al. 2009; Heise and Kotsadam 2015; Hindin and Adair 2002; Tenkorang 2018). This could occur in conflict as a result of the upheaval of social structures - for example, if development programs focus explicitly on women's empowerment (Sengupta and Calo 2016) or if more women 
become heads of household and main breadwinners in places where this is culturally uncommon (Meertens and Segura-Escobar 1996; RajasinghamSenanayake 2004). Women who organize in their communities may be especially at risk, by simultaneously challenging the gendered division of labor and norms about female respectability (Enloe 2000, 126-31).

\section{Reinforcement of Traditional Gender Roles}

During conflict, gender dynamics within couples may revert back to a traditional division between men as empowered and women as disempowered because of fear, insecurity, and displacement.

In a context with narrowly defined masculinity, insecurity can lead men to grasp for control in any way they can, such as becoming more dominant in a partnership. This operates in the same way as the backlash mechanism presented earlier (see also Jones and Ferguson 2009).

Displacement often causes new vulnerabilities for women because of the disruption of social networks that are sources of social control and checks on behavior that could protect them from harm, among other things. Precarity following displacement often forces women into sex work or domestic work under slave-like circumstances as the only available way to make a living (Meertens 2001a, 2001b; Meertens and Segura-Escobar 1996; Mootz et al. 2019; Osorio Pérez 2008; Wirtz et al. 2014). Hence, displacement may put women at risk of IPV. However, FriedemannSánchez and Lovaton (2012) found that conflict-induced migration was associated with reduced risk of physical IPV, perhaps indicating that leaving communities where violence is normalized liberates women from harm. Insecurity may also push women into narrowly defined roles emphasizing their femininity (Connell 2002a), including the need for male protection, which may be linked to women's reluctance or inability to leave violent relationships as described earlier.

\section{GENDERED COMPLEXITIES OF VIOLENCE IN COLOMBIA}

The Colombian armed conflict ignited in the mid-1960s as a surge of leftwing guerrillas tried to influence policy by means of arms. The conflict's roots lie in the country's colonial heritage and core issues such as unequal land ownership, labor conditions, state elitism and bipartisanship, and a substantive democratic deficiency. Actors involved in the fighting include the Colombian government, left-wing guerrillas 
such as FARC and ELN (National Liberation Force), right-wing paramilitary groups, and organized crime cartels. Over the decades, the war has mutated into even more complex logics, linked to the privatization and impunity of violent crimes; tactical assassinations of politicians, journalists, and human rights defenders; and the trade of illicit drugs and arms. Narcotrafficking has been a perpetual fuel for conflict according to the political economy of the global cocaine trade (Bergquist, Peñaranda, and Sánchez 2001; Jansson 2008).

The lives of most Colombians have been spent under violence, which has had multifaceted and gendered consequences. For young men, homicides have been the principal cause of death, and taking up arms has been a way to escape precariousness in a country with tremendously uneven resource distribution. Women, contrarily, have more often been the primary targets of widespread sexual violence and displacement, not least following the murder of a partner (Franco et al. 2006; Garfield and Llanten Morales 2004; Meertens 2001a, 2001b; Meertens and SeguraEscobar 1996; Mootz et al. 2019; Osorio Pérez 2008; Wirtz et al. 2014).

Sexual violence against women has been perpetrated by all armed groups in Colombia. It has been used purposefully to intimidate individuals and communities, extract information, humiliate and hurt enemies, enforce strict rules of conduct, and punish allegiances, transgressions of traditional gender roles, and civil society activism (Kreft 2019, 2020; Meertens 1995, 2001a, 2001b; Meertens and Segura-Escobar 1996; Theidon 2009). Sexual violence has been one of the main drivers of women's displacement, which has further exacerbated their vulnerability. Women have often not considered themselves victims and have generally avoided reporting violations in fear of reprisals and stigmatization. The government has allowed a system of impunity surrounding these crimes. It is impossible to say how prevalent this phenomenon has been, but Afro-Colombian and indigenous women in rural areas have been disproportionally affected according to a discriminatory nexus of gender, ethnicity and precarity. Combining these factors, sexual violence has been normalized (Kreft 2019, 2020; Meertens 1995, 200la, 2001b; Meertens and Segura-Escobar 1996; Theidon 2009). There have been multiple efforts to end the Colombian armed conflict over the decades. The current peace and reconciliation process that disarmed the largest guerrilla, FARC, has uniquely focused on gender. The gender provisions included, among other things, ensuring women's right to land ownership, integrating a gender approach into the mandate of the Truth Commission and organizing special hearings for women, and excluding 
sexual violence from amnesty in the process of transitional justice (Salvesen and Nylander 2017).

\section{EMPIRICAL APPROACH}

Two sets of data are combined to account for women's experiences of conflict and partner violence. The Colombian Demographic and Health Surveys (DHS) offer nationally representative indicators for experiences of and attitudes toward IPV from 2005, 2010, and 2015. Data were pooled to increase statistical power. To correctly observe women's exposure to conflict and avoid self-selection out of "treatment," the sample is restricted to women who did not move from one municipality to another during the time when conflict was observed because there is no information about the location of their previous residence. Estimates were robust to including women who relocated (available upon request). The sample selection consists of 76,692 or 66,760 women who did not relocate in the past year or five years respectively, are aged 13-49, and have ever been in a union, as those are the women who were asked about their experiences of IPV. ${ }^{2}$ Response rates were over $86 \%$ in all rounds (DHS 2005, 2011, 2017).

The Uppsala Conflict Data Program's Georeferenced Event Data measure each event of organized violence in which at least one person was killed, based on global and local media, reports, books, and so on. It includes information on when and where the event happened and the number of deaths in each event (Croicu and Sundberg 2018; Sundberg and Melander 2013). The intensity of conflict in Colombia is illustrated in Figure 2; each bubble indicates an event of conflict, and larger bubbles indicate more casualties in the event.

Because of the longevity of war in Colombia, no pre-post comparison is possible. Instead, the extensive variation in conflict violence intensity across time and space is used to test the relationship between conflict and IPV. The data sets are combined in multiple ways to enable comparisons of estimates and model fit for different measures of conflict. Events and

2. One of the dependent variables (acceptance of IPV) was only available in the survey rounds conducted in 2010 and 2015. In those models, the sample sizes are 66,760 and 46,634 observations, respectively.

The DHS fieldworkers are instructed to skip the IPV questions if anonymity cannot be guaranteed for the safety of the respondents (Ellsberg and Heise 2005). Thus, 1,550 respondents with missing values on all IPV indicators and 851 respondents with nonresponse to all items of attitudes to IPV were removed from analysis. 

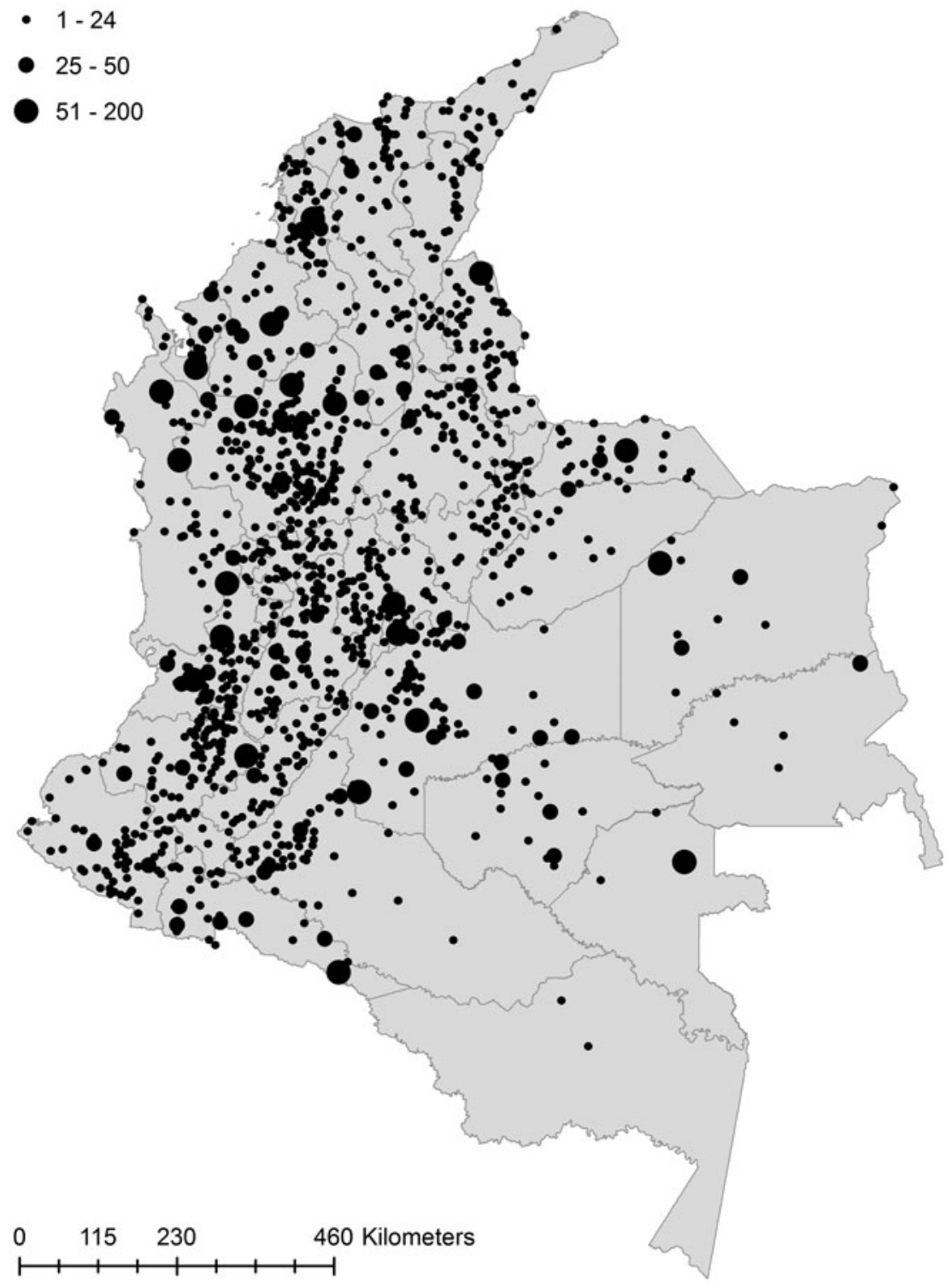

Figure 2. Prevalence of conflict events across Colombia, 1989-2016.

deaths of violent conflict are merged with observations of individual women according to different time frames (one, three, or five years before IPV based on monthly information about when the interviews 
and events of violence occurred) and location (municipalities or departments, i.e., administrative subdivisions ${ }^{3}$ ).

\section{Method}

I use linear probability models (LPMs) to estimate the probability that a certain outcome will occur using a linear combination of effects of independent variables.

Since assignment to "treatment" is not randomized in Colombia but stratified across sociogeographic factors, the method used must consider variation within country subdivisions. Fixed effects and robust standard errors compensate for local omitted factors that could codetermine IPV and armed conflict. This allows the baseline risk of IPV to vary across clusters and uses variation within clusters over time to generate estimates in a multilevel structure (Angrist and Pischke 2009; Stock and Watson 2008). The cluster variable department indicates which of Colombia's 33 departments the respondent lived in at the time of the interview. The range of sampled respondents in each department varied from 1,542 in Guainía to 5,259 in Antioquia.

\section{Dependent Variables}

Four items and indices provided in the DHS are included to measure women's experiences of IPV in the previous year. Experiences of IPV ever in one's lifetime are not included, since it is not possible to ascertain when the violence occurred.

Emotional violence is a composite measure of whether the respondent's (ex-)partner was jealous if she talked to other men, accused her of unfaithfulness, did not permit her to meet female friends, tried to limit contact with her family, insisted on knowing where she was, did not trust her with money, ignored or did not address her, did not request her opinion for family or social gatherings and on important family matters (Cronbach's $\alpha=0.81$ ).

Physical violence indicates whether the respondent's (ex-)partner had pushed, shook, thrown something at, slapped, punched, or hit her $(\alpha=$ $0.75)$.

3. Conflict measures at municipality level may be less valid because the DHS are not representative at that level, municipality divisions have changed across the period, and department-level indicators are more likely to compensate for local migration. 
Severe physical violence captures whether the respondent's (ex-)partner had kicked, dragged, strangled, or burned her or threatened or attacked her with a knife, gun, or other weapon $(\alpha=0.71)$.

Sexual violence measures whether the respondent's (ex-)partner had physically forced her into having unwanted sex.

Acceptance of violence combines five items of whether the respondent answered affirmatively to considering IPV justified in any of the following situations: if a woman goes out without telling her husband, neglects the children, argues with her husband, refuses to have sex with him, or burns the food $(\alpha=0.64)$. The indicators were only available for the survey rounds conducted in 2010 and 2015. Never-partnered women were excluded for consistency with other dependent variables.

Descriptive statistics of the dependent variables measuring experiences and acceptance of IPV in the sample population are presented in Figure 3. There is a gradient in prevalence as more than $50 \%$ of the population had experienced emotional violence, $20 \%$ physical violence, $8 \%$ severe physical violence, and 5\% sexual violence.

To explore whether women who experience IPV remain in relationships, an additional dependent variable measures whether women were partnered and co-residing at interview. Figure 4 displays the shares of those who had experienced the four forms of IPV in the past year or expressed acceptance of violence that were partnered at interview. A larger proportion were partnered among those who experienced emotional or physical violence, while around half the women who had experienced severe physical or sexual violence were partnered at interview. Among those who reported acceptance of IPV, three-quarters were partnered.

\section{Focal Independent Variables}

Numerous specifications of conflict were tested using Akaike's information criterion (AIC) to assess where, how, and when conflict contributes most to model fit. The geographic scope of conflict was compared at the municipality and department levels. The functional form of the relationships between conflict and outcomes was explored comparing linear, dummy, and categorical measures of the conflict intensity. The temporality of the relationships was evaluated by comparing exposure to conflict during the past one, three, and five years, to see whether conflict has a more direct or more long-term impact. Finally, I tested whether conflict measured as number of battle deaths or events contributed more to model fit. 




FIGURE 3. Distribution in sample of women who experienced or accepted IPV.

Four distinct conflict indicators were chosen based on AIC: linear measures of number of events in the past year or past five years in the department where the respondent resided at interview. Other specifications (municipality-level, binary or three-year indicators, or linear measures of number of deaths) did not contribute as much to model fit. $R^{2}$ values did not vary depending on which conflict indicator was used.

\section{Control Variables}

I control for sociodemographic characteristics that may stratify the risk of conflict and IPV. Survey round accounts for period effects. Age groups account for life-course differences. ${ }^{4}$ Partner status measures whether respondent is partnered and co-residing, partnered but not co-residing, widowed, or divorced/separated at time of interview. The respondent's highest level of education is included because women with better

4. AIC tests showed that a categorical measure of age added more to model fit than a linear one. 


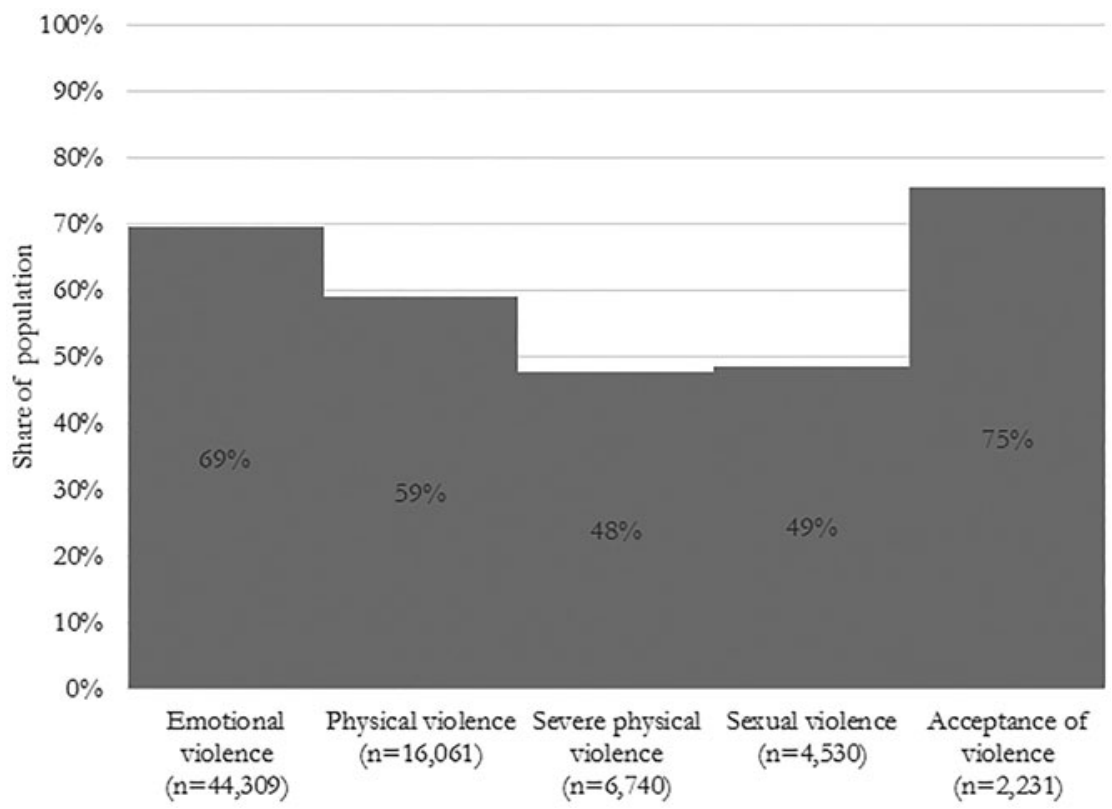

FIGURE 4. The share of women who were partnered at interview among women who reported experiences or acceptance of IPV in the past year.

educational and economic resources may have better chances of leaving abusive relationships as well as conflict-affected areas. ${ }^{5}$ Residence captures whether the respondent lived in a rural or urban area at interview. If the respondent's father ever beat her mother is indicated in the variable family violence.

Descriptive statistics of the study population are displayed in Table 1. Here it is evident that Colombia has had substantial variations in conflict intensity across space and time, as $37 \%$ and $14 \%$ of the sample population had not been exposed to conflict in the past year or past five years, respectively.

5. Household wealth and whether the respondent was working at interview, which are known socioeconomic determinants of IPV, were excluded since these are more likely to be affected by conflict in the past year or past five years. Thus, they should be regarded as mediators, not confounders, and consequently should not be controlled for (Angrist and Pischke 2009). Sensitivity analyses revealed that the results were almost exclusively robust to including these measures, except for when regressing conflict on acceptance of IPV. However, these changed results were minor and not statistically significant. 
Table 1. Descriptive statistics of the sample population

\begin{tabular}{|c|c|c|c|c|c|}
\hline & Observations & Mean & SD & Min & $\operatorname{Max}$ \\
\hline $\begin{array}{l}\text { Number of conflict events in } \\
\text { department, past year }\end{array}$ & 76,692 & 4.38 & 7.59 & 0 & 55 \\
\hline \multirow{2}{*}{$\begin{array}{l}\text { Number of conflict events in } \\
\text { department, past five years }\end{array}$} & 66,760 & 25.67 & 38.47 & 0 & 248 \\
\hline & & Frequency & Percent & & \\
\hline \multirow{3}{*}{$\begin{array}{l}\text { Conflict intensity in } \\
\text { department, past year }\end{array}$} & No conflict & 28,507 & 37.27 & & \\
\hline & Low conflict & 28,784 & 37.45 & & \\
\hline & High conflict & 19,401 & 25.27 & & \\
\hline Total & & 76,692 & 100.00 & & \\
\hline \multirow{3}{*}{$\begin{array}{l}\text { Conflict intensity in } \\
\text { department, past five years }\end{array}$} & No conflict & 9,398 & 14.08 & & \\
\hline & Low conflict & 19,862 & 29.75 & & \\
\hline & High conflict & 37,500 & 56.17 & & \\
\hline Total & & 66,760 & 100.00 & & \\
\hline \multirow[t]{3}{*}{ Survey round } & 2005 & 23,121 & 30.15 & & \\
\hline & 2010 & 31,011 & 40.44 & & \\
\hline & 2015 & 22,560 & 29.42 & & \\
\hline \multirow[t]{7}{*}{ Age in five-year groups } & $13-19$ & 3,492 & 4.55 & & \\
\hline & $20-24$ & 9,345 & 12.19 & & \\
\hline & $25-29$ & 12,323 & 16.07 & & \\
\hline & $30-34$ & 13,153 & 17.15 & & \\
\hline & $35-39$ & 13,232 & 17.25 & & \\
\hline & $40-44$ & 12,912 & 16.84 & & \\
\hline & $45-49$ & 12,235 & 15.95 & & \\
\hline \multirow[t]{3}{*}{ Family violence history } & No & 52,691 & 62.02 & & \\
\hline & Yes & 29,074 & 34.22 & & \\
\hline & Don’t know & 3,187 & 3.75 & & \\
\hline \multirow[t]{3}{*}{ Highest level of education } & Primary or lower & 26,309 & 34.30 & & \\
\hline & Secondary & 35,304 & 46.03 & & \\
\hline & Tertiary & 15,079 & 19.66 & & \\
\hline \multirow[t]{2}{*}{ Residence } & Urban & 55,990 & 73.01 & & \\
\hline & Rural & 20,702 & 26.99 & & \\
\hline \multirow[t]{4}{*}{ Relationship status } & $\begin{array}{l}\text { Partnered, } \\
\text { co-residing }\end{array}$ & 56,007 & 73.03 & & \\
\hline & $\begin{array}{l}\text { Partnered, not } \\
\text { co-residing }\end{array}$ & 3,525 & 4.60 & & \\
\hline & Widowed & 1,849 & 2.41 & & \\
\hline & $\begin{array}{l}\text { Divorced/ } \\
\text { separated }\end{array}$ & 15,311 & 19.96 & & \\
\hline Total & & 76,692 & 100.00 & & \\
\hline
\end{tabular}

Note: Sample statistics for control variables are displayed for women who did not change residence in the past year. 


\section{Limitations}

Because the available data do not allow for an analysis of the frequency of IPV during the past year, this study treated IPV as a certain characteristic of a relationship. Even though the DHS applies the World Health Organization's gold standard for researching IPV, more nuanced measures could improve our understanding of the intensity of partner violence. A related limitation stems from how exposure to conflict is operationalized in this and similar studies; there is no information about how women were personally affected by conflict or perceived the ongoing violence. There is also no information about whether the perpetrator of violence, her (ex-)partner, was involved in military activities or had himself been victimized. In other words, rather than personal trauma the analysis focuses on location-specific exposure, which is - for better and for worse - less subjective.

Since conflict exposure is measured within a department, the distance to each event for individual women varies. Women who live near unit borders may be equally or more affected by events in neighboring departments than by events further away in the same department.

Even if women's conflict exposure is only observed at their current place of residence, women are probably less likely to disclose shorter moves and returns, conflict-induced or not. The analyses are limited by lack of detailed data on women's migration histories, but the main results are robust to a subset of never-movers (available upon request).

Relationship status is included because it is an important confounder for who is at risk of IPV. It is only possible to know what relationship status women had at the time of interview, not at conflict or IPV exposure, both of which may affect relationship status. This limitation is mitigated by the IPV measure also including former partners. Overall, the conclusions do not change when excluding relationship status (available upon request) from the models. Partner's characteristics (such as alcohol consumption) were not available in all survey rounds and therefore were not included.

Any analysis of health outcomes in conflict is prone to survivorship bias. Displaced women, who are particularly vulnerable to GBV in multiple forms, including IPV, are probably not represented. The analyses suffer from underreporting both of IPV, both because of fear and because women who died from IPV cannot give their accounts, and of armed conflict as a result of remoteness and media fatigue. The estimates reported here should be read as floor effects, since we could expect the prevalence of both conflict and IPV to be larger. 
Table 2. Department-fixed effects linear probabilities (and $t$-values) of women's experiences of and attitudes toward intimate partner violence in relation to local conflict violence in Colombia

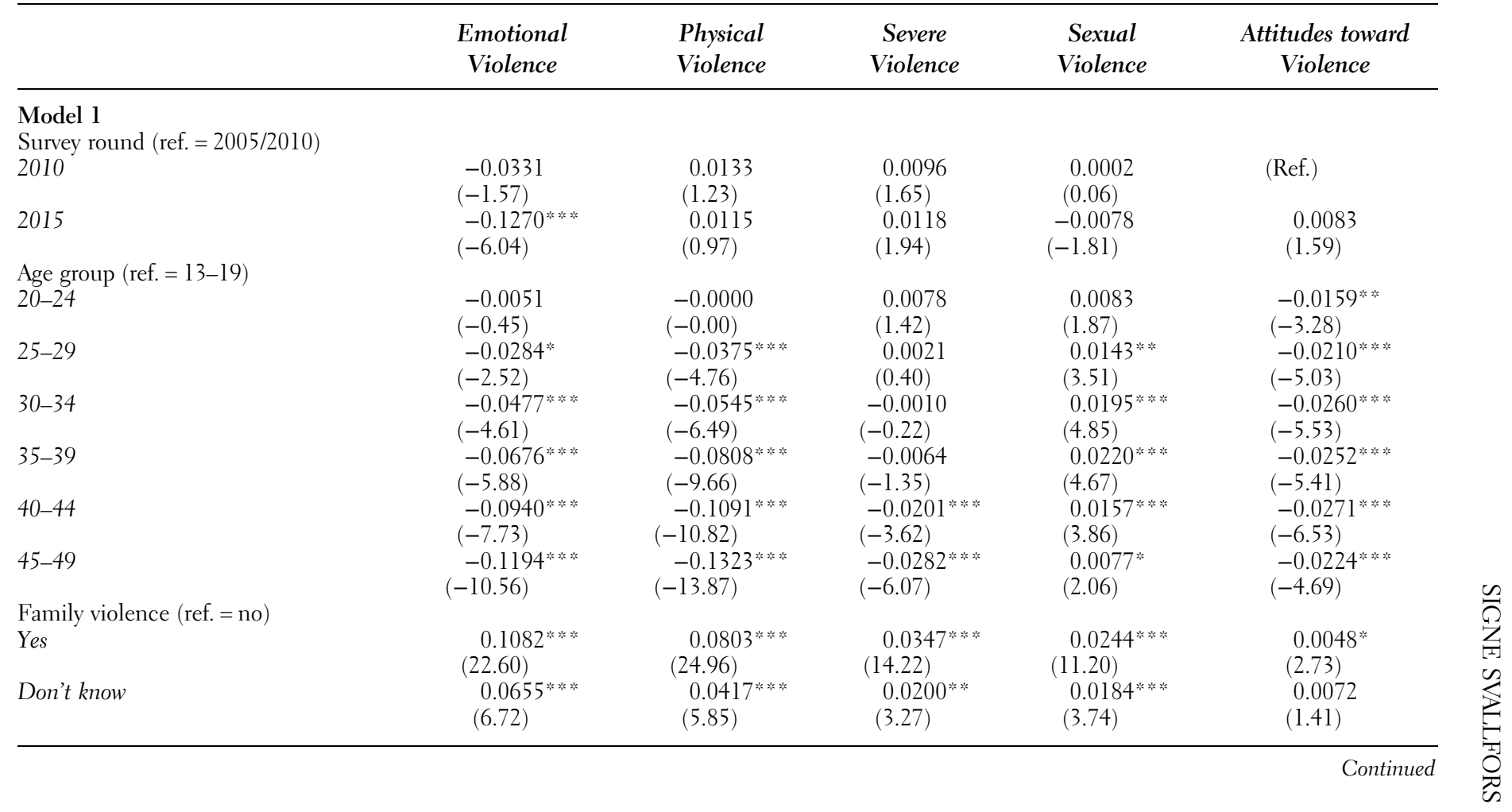




\begin{tabular}{|c|c|c|c|c|c|}
\hline & $\begin{array}{c}\text { Emotional } \\
\text { Violence }\end{array}$ & $\begin{array}{l}\text { Physical } \\
\text { Violence }\end{array}$ & $\begin{array}{l}\text { Severe } \\
\text { Violence }\end{array}$ & $\begin{array}{c}\text { Sexual } \\
\text { Violence }\end{array}$ & $\begin{array}{c}\text { Attitudes toward } \\
\text { Violence }\end{array}$ \\
\hline \multicolumn{6}{|l|}{ Education (Ref. = primary) } \\
\hline Secondary & $\begin{array}{l}-0.0189^{* \ldots+x^{*}} \\
(-4.21)\end{array}$ & $\begin{array}{l}-0.0211^{* \ldots *} \\
(-4.92)\end{array}$ & $\begin{array}{l}-0.0223 \% * \cdots \\
(-7.33)\end{array}$ & 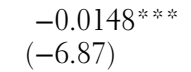 & 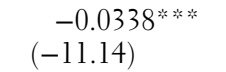 \\
\hline Higher & $\begin{array}{l}-0.0495^{* \ldots *} \\
(-6.69)\end{array}$ & 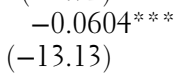 & $\begin{array}{l}-0.0490^{\text {䄅的 }} \\
(-15.25)\end{array}$ & $\begin{array}{l}-0.0262^{* * * ; *} \\
(-10.16)\end{array}$ & 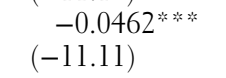 \\
\hline \multicolumn{6}{|l|}{ Residence (Ref. = urban) } \\
\hline Rural & 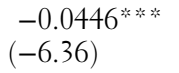 & $\begin{array}{l}-0.0199^{* * * * *} \\
(-4.55)\end{array}$ & $\begin{array}{l}-0.0042 \\
(-1.29)\end{array}$ & $\begin{array}{l}0.0012 \\
(0.46)\end{array}$ & $\begin{array}{l}0.0259^{* * * *} \\
(4.75)\end{array}$ \\
\hline \multicolumn{6}{|c|}{$\begin{array}{l}\text { Partner status }(\text { Ref. }=\text { partnered, co- } \\
\text { residing) }\end{array}$} \\
\hline Partnered, not co-residing & $\begin{array}{l}0.0307^{* * \ldots} \\
(3.46)\end{array}$ & $\begin{array}{l}-0.0167^{* *} \\
(-3.33)\end{array}$ & $\begin{array}{l}-0.0026 \\
(-0.60)\end{array}$ & $\begin{array}{l}-0.0015 \\
(-0.48)\end{array}$ & $\begin{array}{l}-0.0048 \\
(-1.44)\end{array}$ \\
\hline Widowed & $\begin{array}{l}-0.0981 \\
(-7.75)\end{array}$ & $\begin{array}{l}0.0266^{*} \\
(2.42)\end{array}$ & $\begin{array}{l}0.0419 \% \text { 米 } \\
(5.82)\end{array}$ & $\begin{array}{l}0.0144 * \\
(2.14)\end{array}$ & $\begin{array}{l}0.0070 \\
(1.55)\end{array}$ \\
\hline Divorced/separated & 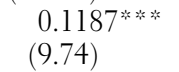 & 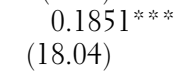 & $\begin{array}{l}0.1341^{* * * * \ldots} \\
(16.85)\end{array}$ & $\begin{array}{l}0.0872 \text { **** } \\
(17.16)^{2}\end{array}$ & $\begin{array}{l}0.0016 \\
(0.83)\end{array}$ \\
\hline Conflict events, past year & $\begin{array}{l}0.0014 \\
(1.49)\end{array}$ & $\begin{array}{l}0.0017^{*} \\
(3.30)\end{array}$ & $\begin{array}{l}0.0011^{* \ldots * *} \\
(4.36)\end{array}$ & 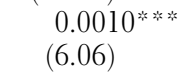 & $\begin{array}{l}0.0003 \\
(0.21)\end{array}$ \\
\hline Constant & $\begin{array}{l}0.5679 * \cdots * \\
(37.55)\end{array}$ & 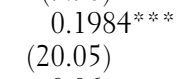 & $\begin{array}{l}0.0573 \text { ( } \\
(9.03)\end{array}$ & 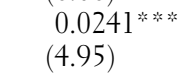 &  \\
\hline$R^{2}$ overall & 0.04 & 0.06 & 0.04 & 0.03 & 0.02 \\
\hline$N$ & 76.692 & 76.692 & 76.692 & 76.692 & 53.571 \\
\hline \multicolumn{6}{|l|}{ Model 2} \\
\hline Conflict events, past five years & $\begin{array}{l}0.0002 \\
(0.97)\end{array}$ & $\begin{array}{l}0.0003 * \\
(2.70)\end{array}$ & 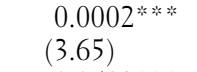 & 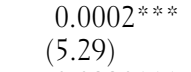 & $\begin{array}{l}-0.0001 \\
(-1.14)\end{array}$ \\
\hline Constant & 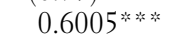 & 0.2015 & 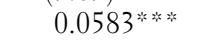 & $0.0230 *$ & 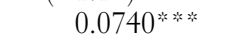 \\
\hline
\end{tabular}


Table 2. Continued

\begin{tabular}{|c|c|c|c|c|c|}
\hline & $\begin{array}{l}\text { Emotional } \\
\text { Violence }\end{array}$ & $\begin{array}{l}\text { Physical } \\
\text { Violence }\end{array}$ & $\begin{array}{l}\text { Severe } \\
\text { Violence }\end{array}$ & $\begin{array}{c}\text { Sexual } \\
\text { Violence }\end{array}$ & $\begin{array}{c}\text { Attitudes toward } \\
\text { Violence }\end{array}$ \\
\hline & $(40.05)$ & $(17.46)$ & $(8.04)$ & $(4.50)$ & $(12.61)$ \\
\hline$R^{2}$ overall & 0.04 & 0.06 & 0.04 & 0.03 & 0.02 \\
\hline$N$ & 66,760 & 66,760 & 66,760 & 66,760 & 46.634 \\
\hline \multicolumn{6}{|l|}{ Model 3} \\
\hline \multicolumn{6}{|c|}{$\begin{array}{l}\text { Conflict intensity, past year } \\
\text { (Ref. = no conflict })\end{array}$} \\
\hline \multirow[t]{2}{*}{ Low } & 0.0120 & 0.0138 & 0.0040 & 0.0026 & -0.0083 \\
\hline & $(0.69)$ & (1.19) & $(0.70)$ & $(0.56)$ & $(-0.83)$ \\
\hline \multirow{2}{*}{ High } & 0.0110 & 0.0264 & 0.0056 & 0.0118 & -0.0021 \\
\hline & $(0.38)$ & $(1.41)$ & $(0.61)$ & (1.98) & $(-0.15)$ \\
\hline \multirow{2}{*}{ Constant } & $0.6011^{\text {******* }}$ & $0.1992^{* * * * *}$ & $0.0637^{* * * * \cdots}$ & $0.0242 \%$ & 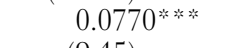 \\
\hline & $(25.71)$ & (12.09) & $(6.24)$ & $(3.39)$ & $(9.45)$ \\
\hline \multirow{2}{*}{$\begin{array}{l}R^{2} \text { overall } \\
\mathbf{N}\end{array}$} & 0.04 & 0.06 & 0.04 & 0.03 & 0.02 \\
\hline & 76,692 & 76,692 & 76,692 & 76,692 & 53,571 \\
\hline \multicolumn{6}{|l|}{ Model 4} \\
\hline \multicolumn{6}{|c|}{$\begin{array}{l}\text { Conflict intensity, past five years (Ref. = } \\
\text { no conflict) }\end{array}$} \\
\hline Low & $\begin{array}{l}0.0464 \\
(1.78)\end{array}$ & $\begin{array}{l}0.0238 * \\
(2.46)\end{array}$ & $\begin{array}{l}0.0102 \\
(1.89)\end{array}$ & $\begin{array}{l}0.0061 \\
(1.12)\end{array}$ & $\begin{array}{l}0.0058 \\
(0.56)\end{array}$ \\
\hline \multirow[t]{2}{*}{ High } & 0.0773 * & $0.0358 *$ & 0.0060 & 0.0013 & -0.0017 \\
\hline & $(2.41)$ & $(2.27)$ & (0.68) & $(0.17)$ & $(-0.14)$ \\
\hline \multirow{2}{*}{ Constant } & 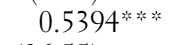 & 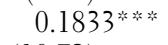 & 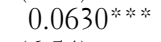 & 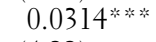 & 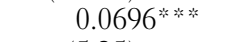 \\
\hline & $(16.55)$ & (10.73) & (6.54) & $(4.33)$ & $(5.35)$ \\
\hline$R^{2}$ overall & 0.04 & 0.06 & 0.04 & 0.03 & 0.02 \\
\hline$N$ & 66,760 & 66,760 & 66,760 & 66,760 & 46,634 \\
\hline
\end{tabular}

Note: Models 2-4 are adjusted for survey round, age, family violence, education, residence, and partner status.

* $p<.05 ;$; * $p<.01 ; * * * * 0.001$, ref. $=$ reference. 


\section{RESULTS}

Table 2 displays the results of the department fixed-effects LPMs. Each outcome is presented in four models with distinct conflict indicators, to assess whether the impact of conflict on IPV is more immediate or long term and whether the functional form of the relationship is linear or categorical. Findings are adjusted by survey year, age, family violence, highest level of education, residence, and partner status at interview. Estimates of control variables are displayed only for Model 1, as they varied little to not at all across the models. AIC and additional full model results are available upon request.

The estimates for the linear conflict indicators show that for each conflict event, the probability of physical, severe physical, and sexual violence is slightly elevated, in Model 1 by around 0.1 percentage points in the past year and in Model 2 by 0.02 points in the past five years. This indicates that the immediate impact of war on IPV is stronger compared with the long term. Emotional violence and acceptance of violence do not have a statistically significant relationship to linear measurements of conflict.

In Model 3, when conflict is measured categorically in the past year and in reference to women who were not exposed, none of the estimates are statistically significant, suggesting that this functional form of conflict indicator is not as relevant as linear measures. In Model 4, if exposed to the highest level of conflict in the past five years, women face an 8-point increase in probability of emotional IPV and a 4-point increase of physical violence. Women exposed to low conflict in the past five years have a 2-point increase in probability of experiencing physical IPV. The other levels are not statistically significant, again pointing away from this functional form.

These findings suggest that there is a persistent relationship between conflict and emotional, physical, severe physical, and sexual IPV. Attitudes toward violence do not have a statistically significant relationship in any of the models, even when including never-partnered women (available upon request). The linear measure of events in the past year is used for subsequent analyses since it appears to be most relevant.

Only the statistically significant relationships of control variables in Model 1 will be discussed in the rest of this section.

The probability of emotional violence is 13 percentage points lower for women interviewed 2015, but there is no evidence of other period effects in IPV. Older age generally protects women from all forms of IPV except sexual violence, which may be partially explained by the decrease in 
acceptance of violence across the life course. It also indicates that emotional and physical IPV start early during the stages of family formation. However, this finding should be treated with caution since the reference group - 13- to 19-year-old women and girls who have already formed their first partnership - is probably highly selective. Severe violence does not decrease until women are in their late 40s. Sexual violence is 1 or 2 percentage points more likely among women above age 25 compared with the youngest women.

If the respondent reports a history of family violence - that her father hit her mother - she is more likely to experience any form of and be more accepting of IPV. Those who do not know about family violence are also more likely to experience IPV, but it is not possible to interpret what this category actually represents.

As expected, those with higher education are less exposed to and less accepting of IPV. Urban residence connects to a lower risk of emotional and physical violence, which may result from reporting bias, a crisis of masculinity when faced with modern city values, or protective social control in rural areas. Rural women are more likely to report acceptance to IPV.

Compared with those living with their partner at interview, women who are not co-residing are slightly more at risk of emotional violence and at lower risk of physical violence. Widows are more at risk of physical, severe physical, and sexual violence but at lower risk of emotional violence. Being divorced or separated consistently and substantially relates to higher risk of IPV, which may reflect women ending violent relationships or facing a violent backlash as revenge after a break-up. Since there is no information about which relationships IPV occurred in, it is difficult to conclusively interpret these findings.

Figure 5 shows predicted probabilities to contextualize the strength of the relationship at different levels of local conflict violence intensity, using the linear indicator of conflict in the past year. Results are adjusted by survey round, age, history of family violence, education level, and partner status. Since accepting attitudes toward IPV were not related to conflict in any model, those marginal effects are not reported.

Across the number of conflict events in the past year, women's probability of IPV increased by $8,8,6$, and 5 percentage points for emotional, physical, severe physical, and sexual violence, respectively. While these effect sizes are rather small, they still represent many more women facing experiences that are extremely harmful to their well-being, and the social consequences of these offenses cannot be minimized. Severe physical and sexual violence 


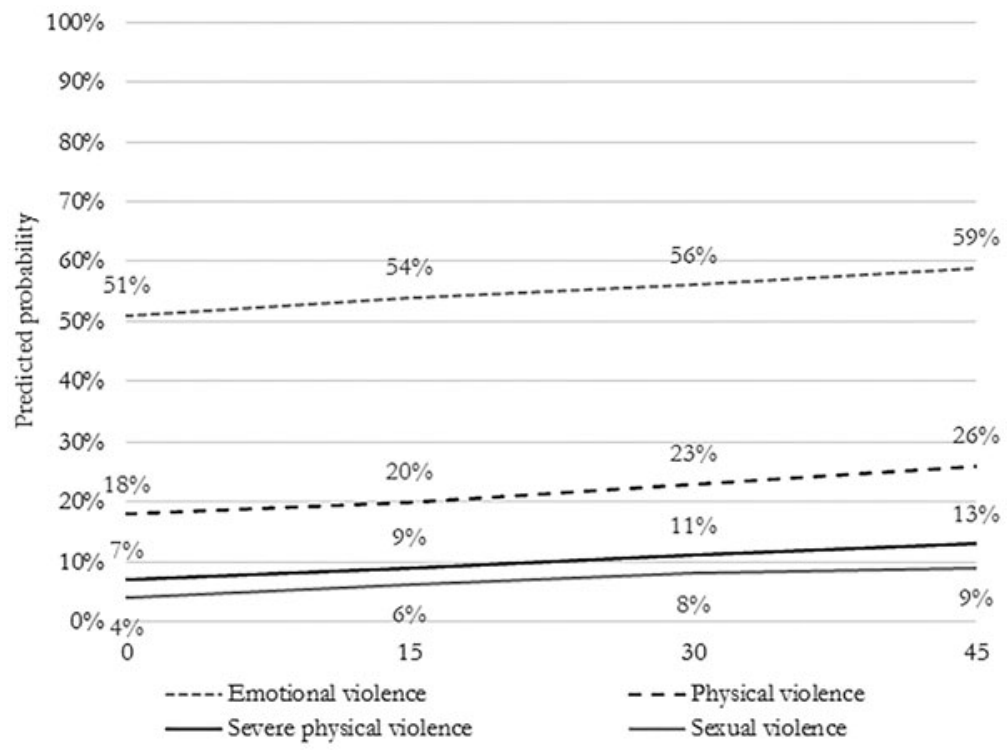

FIGURE 5. Predicted probabilities of IPV according to conflict events in the past year.

increase the most relative to their prevalence: the probability doubles at the highest intensity of conflict observed.

Since the form of GBV analyzed here is perpetrated by women's current or former partner, a closer analysis of whether women are more likely to stay

Table 3. Department-fixed effects linear probabilities (and $t$-values) of being partnered at interview in relation to local conflict violence in Colombia, among women who reported four forms of IPV in the past year

\begin{tabular}{lcccc}
\hline & $\begin{array}{c}\text { Emotional } \\
\text { Violence }\end{array}$ & $\begin{array}{c}\text { Physical } \\
\text { Violence }\end{array}$ & $\begin{array}{c}\text { Severe } \\
\text { Violence }\end{array}$ & $\begin{array}{c}\text { Sexual } \\
\text { Violence }\end{array}$ \\
\hline Model 1 & & & & \\
Conflict events, past year & $0.0017^{* * * *}$ & $0.0032^{* * * *}$ & $0.0035^{* * * *}$ & 0.0028 \\
& $(3.65)$ & $(3.91)$ & $(3.79)$ & $(1.66)$ \\
Constant & $0.3059^{* * * *}$ & $0.3153^{* * * *}$ & $0.4382^{* * * *}$ & $0.3583^{* * * *}$ \\
R-squared overall & $(20.28)$ & $(12.56)$ & $(12.17)$ & $(4.90)$ \\
$\mathbf{N}$ & 0.02 & 0.04 & 0.05 & 0.05 \\
\hline
\end{tabular}

$p<.05 ; * *<<.01 ; * * * 0.001$, adjusted for survey round, age, family violence, education, and residence. 
in abusive relationships because of conflict is useful to understand their risk of victimization. Among women who experienced emotional, physical, and severe physical IPV in the past year, local conflict was associated with a higher probability of being partnered at interview, as displayed in Table 3. Women who reported sexual violence were not more likely to be partnered at interview as a result of conflict. Findings are adjusted for survey round, age, history of family violence, education, and residence. When exploring the same relationship among women who did not report IPV, for a counterfactual check, no such pattern presented itself. For them, some of the linear conflict measures were negatively associated with the probability of being in a relationship at interview, but most relationship statuses were not statistically significant (available upon request). Possible interpretations of these findings are discussed in the next section.

\section{DISCUSSION}

This article has shown that exposure to events of armed conflict is generally linked to an elevated risk for women of experiencing emotional, physical, and sexual violence perpetrated by their intimate partners. Since even small increases in IPV represent many more women facing experiences that are extremely harmful to their well-being, the social significance of these results cannot be minimized. Given that violent conflict and experiences of IPV are both likely underreported, it is probable that the reported estimates represent floor - not true - effects.

The results confirm those from previous studies on IPV at the population level in armed conflict (La Mattina 2017; Østby 2016; Østby, Leiby, and Nordås 2019; Rieckmann 2014), while using temporally fine-grained measures of conflict and disentangling different forms of IPV. As evidenced here, violence at the meso and micro levels are indeed interconnected: exposure to violence in the local context constitutes a risk factor of IPV for individual women. This confirms previous scholarship on how gender and violence are connected on a continuum from the international to the personal (Cockburn 2004). According to this study, the associations were strongest for the graver forms of violence, which could suggest that the normalization of violence in all its forms intensifies with conflict. The short-term impact of conflict was stronger than the long-term impact.

Like La Mattina (2017), there is no evidence that conflict is linked to women's increased acceptance of IPV. However, those items were only 
available in the two latest survey rounds and had little variation (only $4 \%$ of women reported accepting attitudes). The null results in relation to conflict could stem from low statistical power rather than a true zero effect. Scholars have raised concerns that it is unclear whether the DHS items measuring acceptance of IPV reflect respondents' own beliefs or perceptions of the social norm in their setting (Perrin et al. 2019; Schuler, Lenzi, and Yount 2011; Tsai et al. 2017).

The article also contributes with novel analyses of women's relationships, by showing a positive relationship between conflict and the probability of being partnered at interview among victimized women. This could reflect a normalization of violence that makes women stay in abusive relationships, possibly driven by changes in collective norms. If women are under the impression that IPV is a legitimate behavior or they have themselves to blame, they may not end a violent relationship (Stanko 1997). It could also reflect a reluctance among women to leave those relationships because of increased insecurity, need for protection, and worse economic prospects due to war.

Both results could be true, if women are no more normatively accepting of IPV but remain in violent partnerships because they accept victimization and are less harm avoiding because of trauma (Mead, Beauchaine, and Shannon 2010) or perceive they are unable to leave because of heightened insecurity. Given the limitations of the composite acceptance measure, it is difficult to conclusively say how these contrasting findings harmonize. But regardless of why women stay in abusive relationships, it is highly troubling if conflict cements their victimization. These findings could suggest that armed conflict not only is indirectly extremely harmful to women by increasing their risk of multiple forms of IPV, but also exacerbates the vulnerability of women who are already victimized.

The key policy implication from this article is that the focus in the Havana Peace Accord of 2017 on sexual violence was not enough to address all forms of GBV in the Colombian armed conflict. The increased attention to women's wartime experiences, not least of sexual violence, constitutes a big victory for the Colombian women's rights movement and sets the standard for peace and reconciliation processes to come. Still, a sole focus on "public" violence overlooks the hidden casualties from war in the private sphere. The classic feminist notion that "the personal is political" is useful to explain how violence committed in the "public sphere" (i.e., when it has political underpinnings or when the perpetrator is a stranger) is more readily 
acknowledged. The connections between women's experiences of violence in "private" and larger sociopolitical structures are made invisible, even if that violence is more frequent and sometimes more traumatic because of its intimate connotations (Skjelsbæk 2006). Relying on dichotomies of violence - such as battlefront/homefront, extraordinary/everyday, or public/private - risks leading to simplistic understandings with limited capacity to improve the lives of people living in war zones (Browne et al. 2019; Gray 2016a, 2019; Kirby 2015; McWilliams and $\mathrm{Ni}$ Aolain 2014). If the goal of peace initiatives is a positive peace, without any forms of physical and structural violence that could be causes of future conflict (Cockburn 2004; Galtung 1969), violence in intimate partnerships must be addressed alongside sexualized aggressions perpetrated by armed groups. These insights into IPV during war as a human security issue beyond armed groups can inform prevention programs and transitional justice interventions.

The upheavals inherent in civil war and its reparations can open opportunities for change, such as gains in women's political representation (Anderson and Swiss 2014; Webster, Chen, and Beardsley 2019) and new gender relations that replace traditional norms (Connell and Messerschmidt 2005). In Colombia, sexual violence against women and the feminization of internal displacement have provided a space for women's agency and new social roles (Cadena-Camargo et al. 2019; Kreft 2019; Meertens 2001a; Osorio Pérez 2008). Colombia is now at a watershed moment of societal transformation with an ongoing peace process that is uniquely focused on gender equality. Although much work remains to be done, this represents an unprecedented opportunity for addressing GBV in all its forms, including IPV.

\section{RECOMMENDATIONS FOR POLICY}

It is imperative that the government and international development cooperation in Colombia introduce comprehensive GBV primary prevention programs to facilitate change by addressing the underlying root causes of violence. These bodies must also develop careful survivor response systems to address the consequences of GBV and avoid retraumatization: specialized health services including, but not limited to, trauma counseling and sexual and reproductive care, legal support for victims, as well as training and capacity building for professionals in the health system and law enforcement. Both primary and secondary 
prevention should include economic empowerment that would enable women to leave abusive relationships. Involving women-led civil society organizations on the ground and listening to women and girls is essential. Since conditions vary significantly throughout Colombia, community-level engagement allows for discussions with key stakeholders and tailoring culturally sensitive and effective programs for the specific setting, without compromising on human rights. Finally, this endeavor demands fully implementing the Havana Peace Accords, above all with respect to its gender provisions.

Signe Svallfors is a doctoral student in sociological demography in the Department of Sociology, Stockholm University: signe.svallfors@sociology. su.se

\section{REFERENCES}

Ackerson, Leland K., and S. V. Subramanian. 2008. "State Gender Inequality, Socioeconomic Status and Intimate Partner Violence (IPV) in India: A Multilevel Analysis." Australian Journal of Social Issues 43 (1): 81-102.

Alsaba, Khuloud, and Anuj Kapilashrami. 2016. "Understanding Women's Experience of Violence and the Political Economy of Gender in Conflict: The Case of Syria." Reproductive Health Matters 24 (47): 5-17.

Anderson, Miriam J., and Liam Swiss. 2014. "Peace Accords and the Adoption of Electoral Quotas for Women in the Developing World, 1990-2006." Politics E Gender 10 (1): 33 61 .

Angrist, Joshua D., and Jörn-Steffen Pischke. 2009. Mostly Harmless Econometrics: An Empiricist's Companion. Princeton, NJ: Princeton University Press.

Annan, Jeannie, and Moriah Brier. 2010. "The Risk of Return: Intimate Partner Violence in Northern Uganda's Armed Conflict." Social Science \& Medicine 70 (1): 152-59.

Bergquist, Charles, Ricardo Peñaranda, and Gonzalo Sánchez G. 2001. Violence in Colombia, 1990-2000: Waging War and Negotiating Peace. Wilmington, DE: SR Books.

Bibbings, Lois S. 2012. "Men Refusing to Be Violent: Manliness and Military Conscientious Objection, 1914 to the Present Day." In Gender and Conflict since 1914: Historical and Interdisciplinary Perspectives, ed. Ana Carden-Coyne. Basingstoke: Palgrave Macmillan, 41-54.

Browne, Amanda, et al. 2019. "Risk and Refuge: Adolescent Boys' Experiences of Violence in 'Post-Conflict' Colombia." Journal of Interpersonal Violence 36 (19-20): 9393-9415.

Brownmiller, Susan. 1976. Against Our Will: Men, Women and Rape. Harmondsworth: Penguin.

Burazeri, Genc, et al. 2005. "Factors Associated with Spousal Physical Violence in Albania: Cross Sectional Study.” BMJ 331 (7510): 197-201.

Cadena-Camargo, Yazmin, Anja Krumeich, Maria Claudia Duque-Páramo, and Klasien Horstman. 2019. "We Just Been Forced to Do It': Exploring Victimization and Agency among Internally Displaced Young Mothers in Bogotá." Conflict and Health 13: Article 21. 
Carlton-Ford, Steve, Morten G. Ender, and Ahoo Tabatabai. 2008. "Iraqi Adolescents: SelfRegard, Self-Derogation, and Perceived Threat in War." Journal of Adolescence 31 (1): $53-75$.

Clark, Robert A. 1946. "Aggressiveness and Military Training." American Journal of Sociology 51 (5): 423-32.

Cockburn, Cynthia. 2004. "Gender Perspective on War and Peace." In Sites of Violence: Gender and Conflict Zones, eds. Wenona Giles and Jennifer Hyndman. Berkeley: University of California Press, 24-44.

Cockburn, Cynthia, and Dubravka Zarkov. 2002. The Postwar Moment: Militaries, Masculinities and International Peacekeeping: Bosnia and the Netherlands. London: Lawrence \& Wishart.

Cohen, Dara Kay. 2017. "The Ties That Bind: How Armed Groups Use Violence to Socialize Fighters." Journal of Peace Research 54 (5): 701-14.

Connell, Robert W. 2000. "Arms and the Man: Using the New Research on Masculinity to Understand Violence and Promote Peace in the Contemporary World." In Male Roles, Masculinities and Violence: A Culture of Peace Perspective, eds. Ingeborg Breines, Robert W. Connell, and Ingrid Eide. Paris: UNESCO, 21-33.

Connell, R. W. 2002a. Masculinities. 2nd ed. Berkeley: University of California Press.

- 2002b. "Masculinities, the Reduction of Violence and the Pursuit of Peace." In Postwar Moment: Militaries, Masculinities and International Peacekeeping: Bosnia and the Netherlands, eds. Cynthia Cockburn and Dubravka Zarkov. London: Lawrence \& Wishart, 33-40.

Connell, R. W., and James W. Messerschmidt. 2005. "Hegemonic Masculinity: Rethinking the Concept." Gender \& Society 19 (6): 829-59.

Cools, Sara, and Andreas Kotsadam. 2017. "Resources and Intimate Partner Violence in Sub-Saharan Africa." World Development 95: 211-30.

Croicu, Mihai, and Ralph Sundberg. 2018. UCDP Georeferenced Event Dataset Codebook Version 18.1. Uppsala: Uppsala University, Department of Peace and Conflict Research.

Devries, Karen et al., 2011. "Violence against Women Is Strongly Associated with Suicide Attempts: Evidence from the WHO Multi-Country Study on Women's Health and Domestic Violence against Women.” Social Science \& Medicine 73 (1): 79-86.

Devries, K. M., et al. 2013. "The Global Prevalence of Intimate Partner Violence against Women." Science 340(6140): 1527-28.

DHS (Demographic and Health Surveys). 2005. Colombia Salud Sexual y Reproductiva. Bogotá: Profamilia. http://dhsprogram.com/publications/publication-FR172-DHSFinal-Reports.cfm (accessed September 21, 2021).

—_ 2011. Colombia Encuesta Nacional de Demografía y Salud 2010. Bogotá: Profamilia. http://dhsprogram.com/publications/publication-FR246-DHS-Final-Reports.cfm (accessed September 21, 2021).

— 2017. Colombia Encuesta Nacional de Demografía y Salud 2015. Bogotá: Profamilia. http://dhsprogram.com/publications/publication-FR334-DHS-Final-Reports.cfm (accessed September 21, 2021).

Ellsberg, Mary, et al. 2008. "Intimate Partner Violence and Women's Physical and Mental Health in the WHO Multi-Country Study on Women's Health and Domestic Violence: An Observational Study." The Lancet 371 (9619): 1165-72.

Ellsberg, Mary, and Lori Heise. 2005. Researching Violence against Women: A Practical Guide for Researchers and Activists. Washington, DC: World Health Organization, Program for Appropriate Technology in Health.

Enloe, Cynthia. 2000. Maneuvers: The International Politics of Militarizing Women's Lives. Berkeley: University of California Press. 
2002. "Demilitarization - or More of the Same? Feminist Questions to Ask in the Postwar Moment." In Postwar Moment: Militaries, Masculinities and International Peacekeeping: Bosnia and the Netherlands, eds. Cynthia Cockburn and Dubravka Zarkov. London: Lawrence \& Wishart, 22-32.

Franco, Saúl, et al. 2006. "The Effects of the Armed Conflict on the Life and Health in Colombia." Ciência \& Saúde Coletiva 11 (2): 349-61.

Friedemann-Sanchez, Greta, and Rodrigo Lovaton. 2012. "Intimate Partner Violence in Colombia: Who Is at Risk?" Social Forces 91 (2): 663-88.

Galtung, Johan. 1969. "Violence, Peace, and Peace Research." Journal of Peace Research 6 (3): 167-91.

Garfield, Richard, and Claudia Patricia Llanten Morales. 2004. "The Public Health Context of Violence in Colombia." Revista Panamericana de Salud Pública 16 (4): 266-71.

Gindele, Rebecca, et al. 2018. Implementing the Final Colombian Peace Agreement, 20162018. Oslo: PRIO.

Goldstein, Joshua S. 2001. War and Gender: How Gender Shapes the War System and Vice Versa. Cambridge: Cambridge University Press.

Gomez, Anu Manchikanti. 2011. "Sexual Violence as a Predictor of Unintended Pregnancy, Contraceptive Use, and Unmet Need Among Female Youth in Colombia." Journal of Women's Health 20 (9): 1349-56.

Goode, William J. 1971. "Force and Violence in the Family." Journal of Marriage and Family 33 (4): 624-36.

Gray, Harriet. 2016a. "Domestic Abuse and the Public/Private Divide in the British Military." Gender, Place \& Culture 23 (6): 912-25.

- 2016b. "The Geopolitics of Intimacy and the Intimacies of Geopolitics: Combat Deployment, Post-traumatic Stress Disorder, and Domestic Abuse in the British Military." Feminist Studies 42 (1): 138-65.

- 2019. "The 'War'/Not-War' Divide: Domestic Violence in the Preventing Sexual Violence Initiative." British Journal of Politics and International Relations 21 (1): 189-206.

Gupta, Jhumka, et al. 2009. "Premigration Exposure to Political Violence and Perpetration of Intimate Partner Violence among Immigrant Men in Boston." American Journal of Public Health 99 (3): 462-69.

Heise, Lori L. 1994. "Gender-Based Violence and Women's Reproductive Health." International Journal of Gynecology \& Obstetrics 46 (2): 221-29.

__ 1998. "Violence against Women: An Integrated, Ecological Framework." Violence Against Women 4 (3): 262-90.

Heise, Lori L, and Andreas Kotsadam. 2015. "Cross-National and Multilevel Correlates of Partner Violence: An Analysis of Data from Population-Based Surveys." The Lancet Global Health 3 (6): e332-40.

Henry, Nicola. 2016. “Theorizing Wartime Rape: Deconstructing Gender, Sexuality, and Violence." Gender \& Society 30 (1): 44-56.

Hindin, Michelle J., and Linda S. Adair. 2002. "Who's at Risk? Factors Associated with Intimate Partner Violence in the Philippines." Social Science \& Medicine 55 (8): 1385-99.

Hindin, Michelle J., Sunita Kishor, and Donna L. Ansara. 2008. Intimate Partner Violence among Couples in 10 DHS Countries: Predictors and Health Outcomes. Calverton, MD: Macro International Inc.

Jansson, Oscar. 2008. "The Cursed Leaf: An Anthropology of the Political Economy of Cocaine Production in Southern Colombia." PhD diss., Department of Cultural Anthropology and Ethnology, Uppsala University. 
Jones, Adam. 2006. "Straight as a Rule: Heteronormativity, Gendercide, and the Noncombatant Male." Men and Masculinities 8 (4): 451-69.

Jones, James Holland, and Brodie Ferguson. 2006. "The Marriage Squeeze in Colombia, 1973-2005: The Role of Excess Male Death.” Social Biology 53 (3-4): 140-51.

- 2009. "Demographic and Social Predictors of Intimate Partner Violence in Colombia: A Dyadic Power Perspective." Human Nature 20 (2): 184-203.

Kirby, Paul. 2015. "Ending Sexual Violence in Conflict: The Preventing Sexual Violence Initiative and Its Critics." International Affairs 91 (3): 457-72.

Kishor, Sunita, and Kiersten Johnson. 2004. Profiling Domestic Violence: A Multi-Country Study. Calverton, MD: ORC Macro.

Koenig, Michael A., Tom Lutalo, et al. 2003. "Domestic Violence in Rural Uganda: Evidence from a Community-Based Study." Bulletin of the World Health Organization 81 (1): 53-60.

Koenig, Michael A., et al. 2006. "Individual and Contextual Determinants of Domestic Violence in North India." American Journal of Public Health 96(1): 132-38.

Koenig, Michael A., Saifuddin Ahmed, Mian Bazle Hossain, and A. B. M. Khorshed Alam Mozumder. 2003. "Women's Status and Domestic Violence in Rural Bangladesh: Individual- and Community-Level Effects." Demography 40 (2): 269-88.

Kreft, Anne-Kathrin. 2019. "Responding to Sexual Violence: Women’s Mobilization in War." Journal of Peace Research 56 (2): 220-33.

- 2020. "Civil Society Perspectives on Sexual Violence in Conflict: Patriarchy and War Strategy in Colombia." International Affairs 96 (2): 457-78.

La Mattina, Giulia. 2017. "Civil Conflict, Domestic Violence and Intra-Household Bargaining in Post-Genocide Rwanda." Journal of Development Economics 124: 168-98.

McQuestion, Michael J. 2003. "Endogenous Social Effects on Intimate Partner Violence in Colombia." Social Science Research 32 (2): 335-45.

McWilliams, Monica, and Fionnuala D. Ni Aolain. 2014. “'There Is a War Going on You Know' - Addressing the Complexity of Violence Against Women in Conflicted and Post Conflict Societies." Transitional Justice Review 1 (2): Article 2. http://www.ssrn. com/abstract=2404392 (accessed March 2, 2021).

Mead, Hilary K., Theodore P. Beauchaine, and Katherine E. Shannon. 2010. "Neurobiological Adaptations to Violence across Development." Development and Psychopathology 22 (1): 1-22.

Meertens, Donny. 1995. "Mujer y violencia en los conflictos rurales." Análisis Político 24: $36-50$.

— . 2001a. "Facing Destruction, Rebuilding Life: Gender and the Internally Displaced in Colombia." Latin American Perspectives 28 (1): 132-48.

- 2001b. "Victims and Survivors of War in Colombia: Three Views on Gender Relations." In Violence in Colombia, 1990-2000: Waging War and Negotiating Peace, Latin American silhouettes, eds. Charles Bergquist, Ricardo Peñaranda, and Gonzalo Sánchez G. Wilmington, DE: SR Books, 151-69.

Meertens, Donny, and Nora Segura-Escobar. 1996. "Uprooted Lives: Gender, Violence and Displacement in Colombia." Singapore Joumal of Tropical Geography 17 (2): 165-78.

Miedema, Stephanie Spaid, San Shwe, and Aye Thiri Kyaw. 2016. "Social Inequalities, Empowerment, and Women's Transitions into Abusive Marriages: A Case Study from Myanmar." Gender \& Society 30 (4): 670-94.

Milillo, Diana. 2006. "Rape as a Tactic of War: Social and Psychological Perspectives." Affilia 21 (2): 196-205.

Montes, Veronica. 2013. "The Role of Emotions in the Construction of Masculinity: Guatemalan Migrant Men, Transnational Migration, and Family Relations." Gender ङ Society 27 (4): 469-90. 
Mootz, Jennifer J., et al. 2018. "Armed Conflict, Alcohol Misuse, Decision-Making, and Intimate Partner Violence among Women in Northeastern Uganda: A Population Level Study." Conflict and Health 12: Article 37.

—. 2019. "Examining Intersections between Violence against Women and Violence against Children: Perspectives of Adolescents and Adults in Displaced Colombian Communities." Conflict and Health 13: Article 25.

Müller, Catherine, and Jean-Pierre Tranchant. 2019. "Domestic Violence and Humanitarian Crises: Evidence from the 2014 Israeli Military Operation in Gaza." Violence Against Women 25 (12): 1391-1416.

Ng-Mak, Daisy S., Suzanne Salzinger, Richard S. Feldman, and C. Ann Stueve. 2004. "Pathologic Adaptation to Community Violence among Inner-City Youth." American Journal of Orthopsychiatry 74 (2): 196-208.

Osorio Pérez, Flor Edilma. 2008. "Forced Displacement among Rural Women in Colombia." Latin American Perspectives 35 (6): 29-40.

Østby, Gudrun. 2016. "Violence Begets Violence: Armed Conflict and Domestic Sexual Violence in Sub-Saharan Africa." Working Paper 233, Households in Conflict Network. https://hicn.org/working-paper/violence-begets-violence-armed-conflict-anddomestic-sexual-violence-in-sub-saharan-africa/ (accessed September 21, 2021).

Østby, Gudrun, Michele Leiby, and Ragnhild Nordås. 2019. "The Legacy of Wartime Violence on Intimate-Partner Abuse: Microlevel Evidence from Peru, 1980-2009." International Studies Quarterly 63 (1): 1-14.

Pallitto, Christina C., et al. 2013. "Intimate Partner Violence, Abortion, and Unintended Pregnancy: Results from the WHO Multi-Country Study on Women's Health and Domestic Violence." International Journal of Gynecology \& Obstetrics 120 (1): 3-9.

Pallitto, Christina C., and Patricia O'Campo. 2005. "Community Level Effects of Gender Inequality on Intimate Partner Violence and Unintended Pregnancy in Colombia: Testing the Feminist Perspective." Social Science \& Medicine 60 (10): 2205-16.

Parpart, Jane, and Kevin Partridge. 2014. "Soldiering on: Pushing Militarized Masculinities into New Territory." In The Sage Handbook of Feminist Theory, eds. Mary Evans et al. London: Sage Publications, 550-65.

Perrin, Nancy, et al. 2019. "Social Norms and Beliefs about Gender Based Violence Scale: A Measure for Use with Gender Based Violence Prevention Programs in Low-Resource and Humanitarian Settings." Conflict and Health 13: Article 6.

Pollak, Robert A. 2004. "An Intergenerational Model of Domestic Violence." Journal of Population Economics 17 (2): 311-29.

Rajasingham-Senanayake, Darini. 2004. "Between Reality and Representation: Women's Agency in War and Post-Conflict Sri Lanka." Cultural Dynamics 16 (2-3): 141-68.

Rieckmann, Johannes. 2014. "Violent Conflicts Increase the Risk of Domestic Violence in Colombia." DIW Economic Bulletin 12: 23-26.

Rones, Nina, and Kari Fasting. 2017. "Theorizing Military Masculinities and National Identities: The Norwegian Experience." In The Palgrave International Handbook of Gender and the Military, eds. Rachel Woodward and Claire Duncanson. London: Palgrave Macmillan, 145-62.

Salvesen, Hilde, and Dag Nylander. 2017. "Towards an Inclusive Peace: Women and the Gender Approach in the Colombian Peace Process." Norwegian Center for Conflict Resolution, October 7. https://noref.no/Publications/Regions/Colombia/Towards-aninclusive-peace-women-and-the-gender-approach-in-the-Colombian-peace-process (accessed September 21, 2021).

Schuler, Sidney Ruth, Rachel Lenzi, and Kathryn M. Yount. 2011. "Justification of Intimate Partner Violence in Rural Bangladesh: What Survey Questions Fail to Capture." Studies in Family Planning 42 (1): 21-28. 
Schwab-Stone, Mary E., et al. 1995. "No Safe Haven: A Study of Violence Exposure in an Urban Community." Journal of the American Academy of Child \& Adolescent Psychiatry 34 (10): 1343-52.

Sengupta, Anasuya, and Muriel Calo. 2016. "Shifting Gender Roles: An Analysis of Violence against Women in Post-Conflict Uganda." Development in Practice 26 (3): 285-97.

Skjelsbæk, Inger. 2006. "Therapeutic Work With Victims of Sexual Violence in War and Postwar: A Discourse Analysis of Bosnian Experiences." Peace and Conflict: Journal of Peace Psychology 12 (2): 93-118.

Stanko, Elizabeth A. 1997. "Safety Talk: Conceptualizing Women's Risk Assessment as a "Technology of the Soul." Theoretical Criminology 1 (4): 479-99.

Stark, Lindsay, and Alastair Ager. 2011. "A Systematic Review of Prevalence Studies of Gender-Based Violence in Complex Emergencies.” Trauma, Violence, \& Abuse 12 (3): 127-34.

Stock, James H., and Mark W. Watson. 2008. "Heteroskedasticity-Robust Standard Errors for Fixed Effects Panel Data Regression." Econometrica 76 (1): 155-74.

Sundberg, Ralph, and Erik Melander. 2013. "Introducing the UCDP Georeferenced Event Dataset." Journal of Peace Research 50 (4): 523-32.

Svallfors, Signe. 2021. "Reproductive Justice in the Colombian Armed Conflict." Paper presented at the International Studies Association Annual Convention, April 8.

Svallfors, Signe, and Sunnee Billingsley. 2019. "Conflict and Contraception in Colombia." Studies in Family Planning 50 (2): 87-112.

Svec, Joseph, and Tanja Andic. 2018. "Cooperative Decision-Making and Intimate Partner Violence in Peru." Population and Development Review 44 (1): 63-85.

Tamayo-Agudelo, William, and Vaughan Bell. 2019. "Armed Conflict and Mental Health in Colombia.” BJPsych International 16 (2): 40-42.

Tenkorang, Eric Y. 2018. "Women’s Autonomy and Intimate Partner Violence in Ghana." International Perspectives on Sexual \& Reproductive Health 44 (2): 51-61.

Theidon, Kimberly. 2009. "Reconstructing Masculinities: The Disarmament, Demobilization, and Reintegration of Former Combatants in Colombia." Human Rights Quarterly 31 (1): 1-34.

Tsai, Alexander C., et al. 2017. "Measuring Personal Beliefs and Perceived Norms about Intimate Partner Violence: Population-Based Survey Experiment in Rural Uganda." PLOS Medicine 14 (5): el002303.

Vyas, Seema, and Lori Heise. 2016. "How Do Area-Level Socioeconomic Status and Gender Norms Affect Partner Violence against Women? Evidence from Tanzania." International Journal of Public Health 61 (8): 971-80.

Wadham, Ben. 2017. "Violence in the Military and Relations Among Men: Military Masculinities and 'Rape Prone Cultures." In The Palgrave International Handbook of Gender and the Military, eds. Rachel Woodward and Claire Duncanson. London: Palgrave Macmillan, 241-56.

Webster, Kaitlyn, Chong Chen, and Kyle Beardsley. 2019. "Conflict, Peace, and the Evolution of Women's Empowerment." International Organization 73 (2): 255-89.

Wirtz, Andrea L., et al. 2014. "Gender-Based Violence in Conflict and Displacement: Qualitative Findings from Displaced Women in Colombia." Conflict and Health 8: Article 10.

Wood, Elisabeth Jean. 2014. "Conflict-Related Sexual Violence and the Policy Implications of Recent Research." International Review of the Red Cross 96 (894): 457-78. 
Yodanis, Carrie L. 2004. "Gender Inequality, Violence Against Women, and Fear: A Crossnational Test of the Feminist Theory of Violence against Women." Journal of Interpersonal Violence 19 (6): 655-75.

Yount, Kathryn M. 2005. "Resources, Family Organization, and Domestic Violence against Married Women in Minya, Egypt.” Journal of Marriage and Family 67 (3): 579-96.

$\mathrm{Yu}$, Rongqin, et al. 2019. "Mental Disorders and Intimate Partner Violence Perpetrated by Men towards Women: A Swedish Population-Based Longitudinal Study” ed. Phillipa J. Hay. PLOS Medicine 16 (12): el002995. 